CAE Working Paper \#05-17

Labor Laws and Labor Welfare in the Context of the Indian Experience

by

Kaushik Basu

December 2005 
November 2005

\title{
Labor Laws and Labor Welfare in the Context of the Indian Experience
}

[To appear in a festschrift for Erik Thorbecke edited by Alain de Janvry and Ravi Kanbur.]

\author{
Kaushik Basu \\ Department of Economics \\ Uris Hall \\ Cornell University \\ Ithaca, NY 14853 \\ Email: kb40@cornell.edu
}

Acknowledgements: This is a topic on which I have, over the years, had discussions with Gary Fields, Mrinal Datta Chaudhuri, Shub Debgupta, and Martin Rama. I would like to thank them and also Jan Svejnar for helpful comments. 


\section{Introduction}

Markets often work in peculiar ways. A policy that seems obviously good for some groups of people may turn out, when the dust settles and an equilibrium is established, to be detrimental to their welfare. Economics would not have been an interesting subject if this were never the case. One market where such pathologies often occur is the labor market. So it is not surprising that labor market legislation is one area where well-meaning but erroneous policies abound.

In many parts of the world, workers do not seem to have done particularly well and have in fact often lost out in relative terms. This can be because the policy makers did not care but it can also be because they cared but misunderstood the way the labor market works and so their interventions did not work the way they expected they would.

Observers often argue that trade unions use their muscle power to get benefits for organized labor to the detriment of other workers. But in reality it is not evident that organized labor has done that well either. One reason for this is that the relation between the legal and contractual environment of a nation and the well-being of workers is sufficiently complex that trade unions do not always understand what is good for them and so do not demand what is in their interest.

The aim of this paper is to construct plausible theoretical models, using India as the backdrop of stylized facts, to show that this may indeed be the case. It will be argued that India's myriad labor laws, meant to protect laborers, may have actually hurt them. The argument will be presented in terms of a theoretical model and, as such, should be of interest to other developing and transition economies as well. I take the view in this paper, in keeping with the normative position that Erik Thorbecke has espoused time and 
again (Thorbecke, 2003; 2003a) that a society or government has a special responsibility towards the disadvantaged sections of a nation. Hence, in general, laborers should be the target of welfare-enhancing government intervention ${ }^{1}$.

Several pieces of labor legislation in India were drafted expressly to make the laying off of laborers difficult. If an employer found that a worker (1) was shirking from putting in enough effort or (2) did not have adequate skill for the job in question, in many situations he would not be allowed to dismiss the worker (or be allowed to do so only at a considerable cost), no matter what the initial contract with the worker. I shall show that the eventual labor market equilibrium that emerges in an economy with such legislation may actually cause workers to have a lower welfare than in an economy with less protective legislation; and that between legislating to prevent layoffs and legislating to maintain minimum wages, the latter may be the more desirable policy from the point of view of worker welfare.

Section 2 presents some institutional details of the Indian labor market. In the model in Section 3 it will be assumed that labor effort is fixed and so only (2), above, is the relevant issue. It will be shown that in a labor market model, which prima facie captures the broad realities of the Indian economy, an employer's inability to dismiss workers who turn out not to possess the required skill could, in equilibrium, hurt all workers, including the unskilled. The essential argument goes as follows. If worker dismissal is disallowed or very costly, firms which need specialized skills and talents may operate on a smaller scale or, worse, close down. This would of course hurt the skilled workers and, by turning them out to the unskilled labor market, could also lower wages in

\footnotetext{
${ }^{1}$ This is not to deny that there are people who are even more disadvantaged (such as the unemployed, the aged, and the infirm), but as a class, workers are, in most societies, poor enough to deserve attention.
} 
the latter, thereby hurting all workers. There are other possible routes to a similar conclusion. If a firm faces a fluctuating-demand environment and is prevented by law from laying off workers, it may once again close down or function only on a small scale, thereby causing a contraction in the demand for labor and depressing wages (Basu, Fields and Debgupta, 2001). Likewise, consider the case where workers can shirk effort, that is, (1), above, is relevant. In such a situation it is possible that workers may want to be forced to work hard. That would make labor a more coveted input and could increase the demand for labor and wages so much that it would more than compensate the workers for the higher effort. ${ }^{2}$

Before proceeding further I want to emphasize that the modeling here is based on realistic assumptions, but assumptions all the same. Hence, by altering these we can get different results. Nevertheless, it is interesting to see that legislation which is seemingly pro-worker may end up hurting the same workers it is supposed to help. Even if, in reality, this is not always so, the fact that this can happen under realistic assumptions should alert us to the fact that labor laws need more careful scrutiny, theoretical and empirical, to sort out which ones actually help workers and which ones hurt.

\section{The Institutional Background}

Beginning with policy adjustments to stave off a foreign exchange and fiscal crisis in mid-1991, the Indian government has gone on to attempt major economic reforms during the last decade. While significant changes have been effected in several sectors (see Basu, 2004), notably those dealing with international trade and investment,

\footnotetext{
2 Though my analysis is in terms of pre-existing legislation, this is closely related to the question of trade union empowerment and its effect on labor welfare: see Rama (2000) for discussion.
} 
one area which has resisted reform is that of labor markets and labor legislation. This is a matter of some concern since it is arguable that, in the long run, reforms in this area will matter more than those in many other sectors.

Up to now, and in sharp contrast to many other Asian countries, India has failed to deploy her large labor resources to compete better on the domestic and international markets. As a consequence Indian workers remain poor, underemployed and often unemployed. ${ }^{3}$ On the other hand, in India a large number of labor laws have been enacted with the express purpose of protecting labor. ${ }^{4}$ It is the aim of this paper to suggest that these two facts may not be unrelated. To the extent that these laws are wellmeaning and their intent is widely supported, it will be argued here that the condition of the Indian worker represents a major intellectual failure -- the failure to appreciate that overt protection can ultimately do harm when the market has fully responded to the policies and laws and settled down to an equilibrium. In particular, it will be shown that enabling retrenchment and layoffs may result in larger employment and higher wages in the resulting equilibrium. Casual empiricism certainly does not contradict such an hypothesis. The East Asian and South East Asian countries where employment has grown and wages risen are also the countries which, in contrast to India, have fewer protective laws. As Edgren (1989, p. 1) notes at the start of a major I.L.O. study: "legislation governing hiring and firing, minimum wages and the scope for collective bargaining differs between different parts of Asia, with the countries of the Indian

\footnotetext{
${ }^{3}$ There is, in addition, some evidence of employment growth not having kept pace with growth per se in the country. One reason for this is a growing tendency in firms to replace labor with capital (Papola, 1989; Nagaraj, 1993). For a detailed micro study of evolving labor market conditions, see Mathur (1991). The problem of layoffs in connection with the closure of firms is documented in Anant et al (1993). For an excellent study of the whole range of labor legislation in India and its effect of worker welfare, see Singh (2000).

${ }^{4}$ Legislation which is explicitly meant to protect labor interests include The Trade Unions Act, 1926; Industrial Employment (Standing Orders) Act, 1946; Industrial Disputes Act, 1976.
} 
subcontinent having stricter regulations of employers' rights to hire and fire, and granting unions wider scope for bargaining."

The kind of legislation that is of central interest to me here is India's Industrial Disputes Act, 1947. This act, along with the amendments of 1976 and 1982, places restrictions on layoffs and dismissal by large firms. What is important is that these restrictions are exogenous in the sense that they override any contract between the employer and workers. For firms employing 50 or more workers there are predetermined compensations which the employer has to give to workers when they are laid off. For firms employing more than 100 workers the Act requires the employer to take prior permission from government for layoffs and retrenchment of labor and for closing down the firm. And, as Datta Chaudhuri (1994) points out, "government permission is seldom given", and in most employment-related disputes, government gets involved and treats the handling of labor as a child custody problem in a divorce suit. In India, government intervention in labor markets goes much deeper than would appear through studying the labor laws. The Indusrial Disputes Act allows the Labor Departments of the Centre and State governments to intervene not only in labor disputes but also in anticipated labor disputes. In addition there is the problem of political and ministerial intervention (Ramaswamy, 1984). Finally, as mentioned above, the judiciary often takes a custodial attitude to labor. In 1992 in a case involving a bankrupt private firm, a judge of the Calcutta High Court, Mr. Justice Hazari, argued that, if another private firm took over the firm, there would be no guaranteeing that that firm would not, in turn, go bankrupt and cause workers to be laid off. He therefore directed the Government of West Bengal to take over the firm and "run it with the existing workers" (Datta Chaudhuri, 1994). 
It will be shown that it is likely that such laws and practices hurt not only workers who are not protected by the law (because, for instance, they work in small firms), but also the workers who are allegedly protected by law. The fact that protective labor legislation may have hurt India's overall growth and efficiency has been pointed out by many observers (see, eg., Lucas, 1988; Ahluwalia, 1991; Papola, 1994). They are probably right but my argument here is distinct because I am claiming that such legislation may have hurt the very constituency that it was meant to protect, to wit, labor. ${ }^{5}$ Hence, Kannan's (1994) observation that wages in the eighties have not in general kept pace with labor productivity, put forward as a critique of the view that increasing protective legislation has hurt growth and efficiency, and Ghose's (1994) finding that employment per unit of gross value added in manufacturing fell, monotonically, throughout the eighties sit very comfortably with the theoretical findings of this paper. I must stress that what I am arguing for is not for firms to be given the freedom to hire and fire as they wish, but for firms and workers to have greater freedom to sign contracts concerning layoffs, retrenchment and closure, without these being overruled by exogenously determined conditions as wantonly as they currently are.

Suppose some workers in a large firm ask their employer to pay them a higher wage and, in turn, they promise to go away without compensation whenever the employer wishes to sack them. Even if both the workers and the employer benefit by such a contract, it is unlikely in contemporary India that an employer will agree to such a

\footnotetext{
${ }^{5}$ This is also the line taken by Besley and Burgess (2003), who, taking advantage of the fact that labor legislation in India is on the 'concurrent list' (that is, the law can, in principle, be modified by the states) do an inter-state comparison. It is however worth keeping in mind that the variability possible across states in reality is less than what is permitted in principle. This is the reason why the erstwhile Chief Minister of Andhra Pradesh, Chandrababu Naidu, had been arguing that labor legislation should be made entirely a state matter. I believe this is a good suggestion though with the proviso that there should be laws to ensure that the competition across states does not become ruinous.
} 
contract. This is because if, after paying a higher wage for some time, the employer actually gives notice to his workers (perhaps because demand for the product has fallen off), the workers can appeal to government and government is very likely to cite the Industrial Disputes Act and declare such a dismissal illegal no matter what the prior agreement between workers and employer. Indeed there are not too many credible ways for workers to give up their right not to be dismissed. Over here we must distinguish between "not resisting dismissal" and "giving up the right not to be dismissed". A worker can of course choose not to resist dismissal; but what is interesting is that he may not (and, in the case of India, he is not) able to waive the right not to be dismissed.

One kind of reform that my model in Section 3 prompts is to allow employers and workers to sign any contract concerning dismissal conditions and have the state or judiciary uphold such a contract. A less radical but, nevertheless desirable reform would be to leave much of the law, for example, the Industrial Disputes Act, as it is but to add on a clause which gives workers the right to waive the right not to be dismissed as conferred on them currently by the Act. ${ }^{6}$ Such provisos are not unheard of. In the U.S. a student has the right to see the recommendation a professor writes for her, but she also has the right to waive this right.

Before proceeding to construct a formal model, it is worth asking ourselves what is the correct market structure to assume in describing the interaction between firms and workers. Since most of the layoff and dismissal laws apply to large firms, as discussed above, a model with only atomistic firms will not be the right one. At the same time we know that there are lots of firms which do not come under the purview of laws such as

\footnotetext{
${ }^{6}$ The distinction between not giving workers certain rights, $R$, and giving them the rights, $R$, and giving them the further right to waive $R$ is discussed in Basu (1997).
} 
the Industrial Disputes Act by virtue of being too small. Hence, the right model seems to be one with some large or dominant firms that are capable of affecting the market wage, along with a wage-taking fringe of smaller firms. In addition, it will be assumed that it is the large firms which need specialized or skilled labor.

\section{Model: Turnover and Quality}

\subsection{Basic Concepts}

There are certain kinds of skills which are not captured by usual indices like university degrees or I.Q. test scores, but which nevertheless matter to the employer. The skills needed for dealing with people, for remembering little tasks to be performed, and for punctuality often fall in this category. People better endowed with these skills may not necessarily find it easier to acquire education, so even in equilibrium such skills may not be strongly correlated with the degrees and diplomas held by a worker, thus making standard job-market signaling models irrelevant for our present purpose. The only way for an employer to know exactly how much skill of the above kinds a worker possesses is to employ the worker. For reasons of modeling simplicity I shall assume that skill can be of only two levels. Hence workers are either skilled or unskilled. Let us assume that a fraction t of the labor force is skilled. Let the aggregate supply curve of labor be given by

$$
s=s(w), \quad s^{\prime}(w)>0
$$

where $w$ is wage. 
By assuming that both skilled and unskilled workers are otherwise homogenous or that their labor-leisure choices are identical, we know that if a wage of $w$ is fixed, the supply of skilled labor is $t s(w)$ and the supply of unskilled labor is $(1-t) s(w)$.

Next, suppose that there are two kinds of firms -- ones where the worker's skill matters (these are also the large or 'dominant' firms) and ones where they do not (these are the small or 'fringe' firms). From each skilled worker the dominant firms can get an output of $r>0$. They have no use for unskilled labor, who produce 0 in such firms. On the other hand a fringe firm has no special use for skilled labor. Each worker, skilled or unskilled, produces an output less than $r$.

Let me sketch the intuitive argument first. If the dominant firms are not allowed to lay off workers, they will be forced to make do with a labor force in which a fraction $t$ will be skilled and fraction $1-t$ unskilled (since the only way to ensure that you have all skilled workers is to employ people, check them out, lay off the unskilled, employ new people in their place, check them out, and so on). This will typically result in a smaller demand for labor from the dominant firms. Hence the supply of labor in the fringe job market will be greater. This will tend to push down wages. Hence, a law preventing layoffs can actually push down all wages. It is interesting here to note that the detailed empirical study of Fallon and Lucas (1993) reveals that demand for labor in large firms fell as legislation preventing labor dismissal was made stronger. And Fallon and Lucas (p. 269) go on to conjecture: "This decline may be understood in terms of [...] reluctance to hire in case employees prove to be poor matches with their job demands, a mismatch which cannot readily be reversed". ${ }^{7}$

\footnotetext{
${ }^{7}$ If we assume some wage rigidity, these arguments can easily translate to the effect of anti-dismissal laws on unemployment. Such a law (see, eg., Layard, Nickell and Jackman, 1994, p. 108) clearly has opposing
} 
In the model that follows I shall make special assumptions to keep the algebra simple but the aim is to formalize the above general argument.

As explained in the previous section, the fringe firms will be treated as wagetakers, whereas the dominant firms are like oligopsonists in the labor market. Hence, we are considering a labor market similar to the product-model of Nichol (1930) and Stigler (1950) and more recently, extended and discussed by Encaoua and Jacquemin (1980), Dixit and Stern (1982), and Basu (1993).

Let the fringe firms' aggregate demand for labor be given by:

$$
d=d(w), \quad d^{\prime}(w)<0
$$

Hence, if $w$ is the wage, the supply of labor in excess of what is needed by the fringe firms is given by

$$
\psi(w)=s(w)-d(w)
$$

Let us suppose that there are $k$ dominant firms. If these firms choose workers randomly, the expected output from a worker is $r t(=r t+0(1-t))$. If these firms are not allowed to lay off workers then the expected output from each employed worker is $r t$. If, on the other hand, the firms can freely dismiss workers then, we shall assume, worker productivity to be $r$. This is because through successive laying off of unproductive workers, the dominant firms' labor force will converge to a purely skilled group.

Each dominant firm's cost of production consists of an entry fee of $K(>0)$ and the wage bill.

ex ante and ex post effects, so that the net impact on employment can be ambiguous. Hence, a law making labor dismissal harder may result in a larger unemployment. Though Layard, Nickell and Jackman reach a similar conclusion, they point out that empirical studies do not provide any clear resolution of this ambiguity. 
Our model consists of two periods. In period 1, each of the $k$ dominant firms have to decide whether to enter the industry or not. Then in period 2 the ones that enter decide how much labor to employ, keeping in mind that their decision will affect the labor demand of the fringe firms. Our aim is to characterize the subgame perfect equilibrium of this two-period game. Actually, we have two games. One in which layoffs are allowed and one in which the law prevents layoffs. Our aim is to compare the equilibria in these two games.

There are, in reality, many intermediate cases. For instance, a law could make layoffs costly, instead of disallowing layoffs. As discussed above, India's Industrial Disputes Act does exactly that for firms employing between 50 and 100 workers. Fortunately, such cases are easy to discuss once we have worked out the two polar models.

I shall characterize the subgame perfect equilibria by first analyzing the Nash equilibria in the second period game when no layoffs are permitted (Section 3.2) and when layoffs are permitted (Section 3.3) and then turn to the outcomes in the full twoperiod model (Section 3.4). If $m$ dominant firms enter the industry and layoffs are not permitted, the second period game is described as $G(m, N)$. The second period game with $m$ dominant firms and layoffs permitted is called $G(m, L)$.

\subsection{The Game $G(m, N)$}

There are $m$ dominant firms that have entered the industry, and confront the labor supply function $\psi(w)$, described in (3). Let the inverse of this function be given by $\varphi(\cdot)$. 
If the firms hire $n_{1}, \ldots, n_{m}$ units of labor, recalling that no layoffs are allowed in this model the profit function of firm $i$ is given by

$$
\pi_{i}^{N}\left(n_{1}, \ldots, n_{m}\right)=r t n_{i}-\phi\left(n_{1}+\ldots+n_{m}\right) n_{i}
$$

This is the model used by Encaoua and Jacquemin (1980), though in their model the dominant firms and the fringe compete in the product market. I shall here focus on the symmetric Nash equilibrium of this m-player game. In the examples that I consider below such an equilibrium always exists and, in fact, is the only Nash equilibrium. Hence, each firm employing $n^{N}$ labor is an equilibrium if and only if, for all $i \varepsilon\{1, \ldots, m\}$.

$$
\pi_{i}^{N}\left(n^{N}, \ldots, n^{N}\right) \geq \pi_{i}^{N}\left(n^{N}, \ldots, n^{N}, n_{i}, n^{N}, \ldots, n^{N}\right), \quad \text { for all } n_{i} .
$$

If $n^{N}$ is the equilibrium in $G(m, N)$, define ${ }^{8}$

$$
\pi^{N}(m) \equiv \pi_{i}^{N}\left(n^{N}, \ldots, n^{N}\right)
$$

Hence, $\pi^{N}(m)$ is the profit earned in the period 2 equilibrium by each firm when there are $m$ firms and no layoffs (hence the superscript $N$ ) are allowed. In equilibrium the fringe firms hire $d\left(\phi\left(m n^{N}\right)\right)$ laborers and pay wage equal to $\phi\left(m n^{N}\right)$.

While this completes the description of the outcome of $G(m, N)$, let me introduce a geometric description of the problem which could aid intuition later in the more complicated case.

[Figure 1]

\footnotetext{
${ }^{8}$ We are proceeding under the assumption of there being a unique equilibrium - an assumption that holds true in the class of examples considered below.
} 
If the aggregate supply curve, $s(w)$, and the demand curve of the fringe firms, $d(w)$, are as shown in Figure 1, then the supply curve faced by the dominant firms is given by $\mathrm{ABC}$ where $\mathrm{AB}$ is drawn such that for any wage $w$, the line $w a$ is equal to $b c$. The final equilibrium is then the usual oligopsony equilibrium for $m$ firms facing the supply curve ABC.

\section{The Game $G(m, L)$}

There are $m$ dominant firms that have entered the industry and they are allowed to layoff workers. This means that (in the end) these firms will only employ skilled workers and get an output of $r$ from each employed worker. Hence, the supply curve of the labor that is of relevance to these firms is given by $t s(w)$. What we have to be careful about is that if the wage that the dominant firms pay drops too low then some of the skilled laborers may prefer to go to the fringe firms. Keeping this in mind, let us now work out the aggregate demand function that these dominant firms face.

Define the wages, $\bar{w}$ and $\underline{w}$, as, respectively,

$$
d(\bar{w})=(1-t) s(\bar{w})
$$

and

$$
d(\underline{w})=s(\underline{w})
$$

In this model with layoffs the skilled workers can get a different wage from unskilled workers. Let $w^{1}$ be the wage earned by each skilled worker and $w^{0}$ the wage of an unskilled worker. 
If $w^{1}>\bar{w}$, the supply of skilled workers to the dominant firms is $t s\left(w^{1}\right)$ and $w^{0}=w$. If $w^{1} \leq \bar{w}$, the supply of workers to the dominant firms is $s\left(w^{l}\right)-d\left(w^{l}\right)$ and $w^{0}=w^{1} \cdot{ }^{9}$ The dominant firms will ensure that the workers they employ are skilled workers. This is feasible since

$$
s\left(w^{I}\right)-d\left(w^{l}\right)<t s\left(w^{l}\right),
$$

which is an implication of $w^{I} \leq \bar{w}$.

The information in the above paragraph is summed up, by writing the supply function of skilled workers faced by the dominant firms as:

$$
S\left(w^{1}\right)=\left\{\begin{array}{ll}
t s\left(w^{1}\right), & \text { if } w^{1} \geq \bar{w} \\
s\left(w^{1}\right)-d\left(w^{1}\right), & \text { if } w^{1}<\bar{w}
\end{array} .\right.
$$

If $\theta(\cdot)$ is the inverse of $S\left(w^{I}\right)$, the profit function of firm $i$ is given by

$$
\pi_{i}^{L}\left(n_{1}, \ldots, n_{m}\right)=m_{i}-\theta\left(n_{1}+\ldots+n_{m}\right) n_{i},
$$

the superscript $L$ being a reminder that this is a model with layoffs.

Figure 2 illustrates (5). The right-hand panel of Figure 2, shows $d(w)$ and $s(w)$, as in Figure 1, and in addition illustrates $t s(w)$. The left-panel shows $d(w)$ and $(1-t) s(w)$.

\section{[Figure 2]}

The supply curve (5) is given by the line ADE. Note that in the case without layoffs the supply curve was given by ABC. Hence, the supply now faced by the dominant firms is smaller. But, of course, all laborers employed by the dominant firms now are skilled laborers.

\footnotetext{
${ }^{9}$ If $w^{I}<\underline{w}$, the supply to the dominate firms is, of course, zero.
} 
Following the exercise in Section 3.2, we define $n^{L}$ to be equilibrium employment by each firm in game $G(m, L)$ if, for all $i$,

$$
\pi_{i}^{L}\left(n^{L}, \ldots, n^{L}\right) \geq \pi_{i}^{L}\left(n^{L}, \ldots, n^{L}, n_{i}, n^{L}, \ldots, n^{L}\right)
$$

for all $n_{i}$.

Define,

$$
\pi^{L}(m)=\pi_{i}^{L}\left(n^{L}, \ldots, n^{L}\right)
$$

Hence, $\pi^{L}(m)$ is the profit earned in the period 2 equilibrium by each firm when there are $m$ firms and layoffs are permitted.

If $\theta\left(m n^{L}\right)>\bar{w}$, the fringe firms pay a wage of $\mathrm{w}$ in equilibrium. Otherwise they pay a wage of $\theta\left(m n^{L}\right)$.

\subsection{Subgame Perfect Equilibria With or Without Layoffs}

It is now easy to work out the subgame perfect equilibria of the two two-period games that we have, one with the second period game $G(m, N)$ and the other with $G(m, L)$. Call the two two-period games $G^{N}$ and $G^{L}$, respectively.

Consider first the case where no layoffs are allowed, that is, game $G^{N}$. Let the ordered pair, $(t, n)$, denote the number of firms, $t$, that decide to enter the industry in period 1 and the number of units of labor, $n$, that each entrant firm employs in period 2 . Recall that if a firm enters and earns $\pi$ in the post-entry game, the firm's net profit is $\pi$ $K$, and also that $k$ is the total number of potential entrants.

$\left(t^{*}, n^{*}\right)$ is described as a subgame perfect equilibrium of $G^{N}$ if 
i. $\quad t^{*}=k$ and $\pi^{N}(k)-K \geq 0$, or

ii. $\quad t^{*}=0$ and $\pi^{N}(1)-K \leq 0$, or

iii. $\quad 0<t^{*}<k$ and $\pi^{N}\left(t^{*}\right)-K \geq 0$ and $\pi^{N}\left(t^{*}+1\right)-K \leq 0$, and

iv. $\quad n^{*}$ is an equilibrium in $G\left(t^{*}, N\right)$.

The subgame perfect equilibrium of $G^{L}$ is defined in the same way with $\pi^{L}$ replacing $\pi^{N}$ and $G\left(t^{*}, L\right)$ replacing $G\left(t^{*}, N\right)$.

If legislation like the Industrial Disputes Act is repealed, the labor market game will switch from $G^{N}$ to $G^{L}$. Our aim is to compare the resulting new equilibrium with the equilibrium in $G^{N}$. While all kinds of welfare changes are possible, I focus here on the relatively counter-intuitive one and demonstrate that laborers -- all laborers -- can be better off under $G^{L}$.

I shall demonstrate this by confining attention to a class of linear models. In particular, I shall assume

$$
\begin{aligned}
& s(w)=b w \\
& d(w)=A-B w
\end{aligned}
$$

Hence (4) now becomes

$$
\pi_{i}^{N}\left(n_{1}, \ldots, n_{m}\right)=\left[r t-\frac{\sum n_{j}}{b+B}-\frac{A}{b+B}\right] n_{i}
$$

It must be recalled that this is valid, assuming that equilibrium wage does not exceed $\mathrm{A} / \mathrm{B}$, because otherwise fringe demand is zero. That is, 


$$
\frac{m}{m+1}[(b+B) r t-A] \leq \frac{b A}{B}
$$

It is easy to compute the amount produced and the profit earned by each firm under symmetric Nash equilibrium or what is simply called the equilibrium in Section 3.2.

These are given by

$$
\begin{aligned}
& n^{N}=\frac{r(b+B)-A}{m+1} \\
& \pi^{N}(m)=\left[\frac{r t(b+B)-A}{m+1}\right]^{2} \cdot \frac{1}{b+B}
\end{aligned}
$$

Let us now turn to the case where layoffs are permitted. From the definition of w and using (7) and (8) we get:

$$
\bar{w}=\frac{1}{(1-t) b+B}
$$

From (5) and (6), it follows that

$$
\pi_{i}^{L}\left(n_{1}, \ldots, n_{m}\right)= \begin{cases}{\left[r-\frac{\sum n_{j}}{t b}\right] n_{i},} & \text { if } \frac{\sum n_{j}}{t b} \geq \frac{A}{(1-t) b+B} \\ {\left[r-\frac{\sum n_{j}+A}{b+B}\right] n_{i},} & \text { if } \frac{\sum n_{j}}{t b}<\frac{A}{(1-t) b+B}\end{cases}
$$

Let us suppose that the top line of the above function is relevant. Then

$$
n^{L}=\frac{r t b}{m+1}
$$

and

$$
\pi^{L}(m)=\frac{r^{2} t b}{(m+1)^{2}}
$$


and

$$
\frac{m r}{m+1} \geq \frac{A}{(1-t) b+B}
$$

The last inequality merely ensures that the top line of the $\pi_{i}^{L}$ function is relevant. If (11) is untrue, $n^{L}$ and $\pi^{L}(m)$ will be given by (9) and (10).

Suppose we have a situation where (11) holds and also $\pi^{L}(\mathrm{~m})>\pi^{N}(\mathrm{~m})$. That is,

$$
r^{2} t b>\frac{[r t(b+B)-A]^{2}}{b+B}
$$

In that case, we can find a $K>0$ such that

$$
\pi^{L}(1)>K>\pi^{N}(1)
$$

or

$$
\frac{r^{2} t b}{4}>K>r^{2}\left[\frac{r t(b+B)-A}{2}\right]^{2} \cdot \frac{1}{b+B}
$$

If, for instance, $r=2, t=\frac{1}{2}, B=8, A=8$ and $K=\frac{3}{4}$, then (11) and (12) are true (with $m=1$ in (11)).

If (11) and (12) are true, there will be no dominant firms in the industry if layoffs are banned, since $\pi^{N}(1)-K<0$. But if layoffs are allowed, entry is bound to occur since $\pi^{L}(1)-K>0$. So if layoffs are banned all workers will be getting a wage of $\underline{w}$, where, as before, $d(\underline{w})=s(\underline{w})$. If such a ban is revoked, some dominant firms, which need skilled labor, will enter the industry. They will of course pay their workers a higher wage. And, by virtue of their employing workers, the supply of labor to the fringe sector will fall. Hence, the fringe sector wage will rise. 
By confining attention to situations where $\pi^{L}(1)>K>\pi^{N}(1)$, we here get the result that there will be no entry of firms using skilled labor if layoffs are not permitted. In that case we can assert that allowing for layoffs will cause an expansion in the sector using skilled labor thereby pulling up wages for all workers. The scenario is not at all unlike what has been observed in many developing countries, such as India. There is skilled labor and a lot of scope for using the labor; but the labor laws prevent adequate use of this labor.

In the present model we focused on one kind of causation. Firms need to try out workers, dismiss some, employ others and so on in order to improve the skill-level of their labor force. Laws which make layoffs impossible discourage the emergence and growth of such firms. There are other kinds of causation, for instance, that involving the workers' choice of effort which could push us towards the same conclusion. The latter is studied in Section 4.

\subsection{Costly Layoff}

Up to now we focused on the polar cases of "costless layoffs" and "no layoff". Now suppose there is a law that requires that firms pay a compensation of c units to every worker that is dismissed. The firm will then face a choice of either employing randomly picked workers and not laying them off in which case a fraction $(1-t)$ of its work force will be unproductive as in game $G(m, N)$ or incurring the compensation cost but moving towards a skilled labor force. If the firm wishes to employ $n_{i}$ workers who are skilled, it could, for instance, employ $n_{i}$ dismiss the $(1-t) n_{i}$ who turn out to be unproductive, 
employ $(1-t) n_{i}$ new workers, dismiss $(1-t)^{2} n_{i}$ of them who turn out unproductive, and so on. The total number of dismissals will be:

$$
\left(\frac{1-t}{t}\right) n_{i}=(1-t) n_{i}+(1-t)^{2} n_{i}+(1-t)^{3} n_{i}+\ldots
$$

Ignoring the process by which this is achieved and treating it as instantaneous we would write firm $i$ 's profit function as

$$
\pi^{i}=\left[r-\theta\left(n_{1}+\ldots+n_{m}\right)-\frac{c(1-t)}{t}\right] n_{i}
$$

where $\theta(\cdot)$ is the same as in (6). Whether a firm finds it worthwhile to replace its unskilled worker with a skilled worker depends on whether

$$
r-r t \geq c(1-t) / t
$$

It is quite obvious that if $\mathrm{c}$ is large enough we could have the same kind of result as demonstrated above. The dominant firms will either not enter at all or not expand, thereby causing a glut of labor on the fringe market and depressing wages.

\subsection{Minimum Wages}

The implementation of legal minimum wages is quite ubiquitous across nations. In India, the Minimum Wages Act, 1948, empowers the government to announce legally minimum wages and periodically revise these. ${ }^{10}$ Failure on the part of an employer to adhere to this is "punishable with imprisonment [up to] six months, or a fine [up to] five hundred rupees, or with both". Despite this, in practice, the minimum wage law is frequently contravened in India. ${ }^{11}$

\footnotetext{
10 The Act also specifies other details, like hours of work and, over time rates.

${ }^{11}$ Compliance with this law turns out to be far from perfect even in developed countries. Ashenfelter and Smith's (1979) study of the U.S. labor market of the early seventies shows that there was 65 percent
} 
In the above model it can be shown that, unlike anti-layoff laws or custom, minimum wage laws have a desirable effect on labor welfare if they are applied only to the dominant firms and in small measure. There could be other, more ubiquitous reasons for having minimum wage laws, as argued in Basu, Genicot and Stiglitz (2003), but the analysis here is confined within the structure of the above model.

This is easy to see. The usual reason why some economists argue against the use of a minimum wage is transparent by an appeal to the conventional demand and supply curve analysis of labor-market equilibrium. In such a model, a minimum wage law can indeed raise wages but this also causes unemployment. Hence it benefits some workers but only by hurting other workers.

The above reasoning however does not carry over to the model built in this paper, when the minimum wage law is applied to the oligopsonists. To demonstrate this with the simpler model, suppose that layoffs are not permitted. Consider the game $G(m, N)$, that is, a game with no layoffs and m large firms. Figure 3 reproduces $s(w)$ and $d(w)$ from Figure 1.

[Figure 3]

In addition, the figure marks $F$ on the wage axis, which shows the expected amount earned by a firm from a randomly chosen laborer (i.e. $O F=r t$ ). Since the supply

compliance. They are careful to define compliance not as percentage of laborers who get a wage above the statutory minimum, but as the percentage of workers who earn the statutory minimum wage or lose their jobs among workers who would earn less than the statutory minimum wage in the absence of a minimum wage law. Though I cannot cite evidence, it seems natural to me to expect that minimum wage regulation would be violated more widely than anti-dismissal legislation. This is because when striking a deal for a new job, it may be in the worker's interest to comply with a less than minimum wage (because otherwise he may not get the job) but when served a dismissal notice a worker has no interest in complying with the employer's demand. 
curve of labor faced by the oligopsonists is $A B C$, a standard analysis suggests that the oligopsonists will employ $O L$ laborers ( $O L$ being $m /(m+1)$ of the length of the line $F D$ ) with each oligopsonist employing $O L / m$ laborers, and equilibrium wage being $\hat{w}$. Even the fringe sector will pay $\hat{w}$ (and employ $E G$ laborers) in equilibrium.

Now consider a minimum wage a little above $\hat{w}$. That may result in some of the (large) firms to not enter the industry. If $\hat{w}$ is so high that no firm enters the industry then wage will drop to $O A$ in Figure 3 and laborers will be worse off. But as long as that does not happen, that is, some large firms continue to produce, the laborers benefit because of the minimum wage legislation. If $\tilde{w}$ is such that $\tilde{w}>\hat{w}$ and $\tilde{w} H J F=K$ (the entry cost), then any minimum wage which is below $\mathrm{w}$, benefits the laborers. ${ }^{12}$

The above analysis suggests that if the welfare of workers is of concern to the government, it may be best to repeal anti-layoff legislation (that is, as explained earlier, the terms and conditions of layoffs should be decided by the workers and their employer through free contracting) but to have some minimum wage requirements for large firms (not for the small fringe firms).

\section{Conclusion}

Modern economists are aware -- or at any rate ought to be -- that markets often fail, and even when they do not fail they may result in intolerable inequities. From this truism to jump to the conclusion that government should be brought in wherever the market is expected to fail is however a fallacy. Just as markets can fail, so can

\footnotetext{
${ }^{12}$ A recent study by Card and Krueger (1994) finds that an upward revision of the minimum wage in New Jersey increased employment in the fast-food industry (see also Card, 1992). As the authors point out, this is not surprising if the labor market is oligopsonistic (though in their study there are other changes which cast some doubt on the market being an oligopsony). See Drazen (1986) for an argument why minimum wage legislation may be efficient.
} 
governments. It is entirely possible that government will act as a handmaiden of vested interests or will simply be ineffective and falter. In the context of labor, markets do often fail. This means that we may need certain kinds of non-market interventions to ensure minimal labor standards and basic worker rights. Yet, the steps from this realization to its execution can be fraught with pitfalls, unless we do this on the basis of very careful theorizing and documenting of facts. The aim of this paper was to sound this warning bell.

This paper evaluated labor laws concerning layoffs and minimum wage legislation in India and, on the basis of a theoretical model, reached the following policy conclusions. It argued that legislation or even customary practice which makes the laying off of labor illegal or (exogenously) costly may be harmful for the workers. The same may happen if employers are a priori given the freedom to fire workers at will. Instead, workers and employers should have the freedom to develop their own contract concerning the conditions for the dismissal of labor. There will be reason to set limits on the range of contracts allowable (without this, contracts run the risk of becoming so complex that workers may not fully comprehend what they are committing themselves to), but there is reason to believe that a larger freedom than what is current permitted would benefit workers. I would expect that many firms needing specially skilled labor would, in the first place, come into existence and, secondly, agree to give higher wages and expand their labor force if such an amendment to existing laws were to be made.

This paper argued that there may be a need to impose some legislative restrictions on minimum wages. In particular, workers will benefit by having some minimum wage restrictions, as long as these are not set too high and as long as these are confined to the 
large firms. Of course, if the layoff legislation is amended as suggested here, the market wage paid by the large firms may well outstrip the legal minimum wage naturally. This is consistent with the experience of Taiwan and Korea (Ranis, 1994).

From these broad do's and dont's, to answer specific questions, such as how high should minimum wages be, or, when allowing workers to sign contracts to give up the existing right not to be dismissed, what restrictions should be placed on the allowable range of contracts, we need to move to empirical and descriptive research. The purpose of this paper was to provide an analytical basis for such work. 


\section{References}

Ahluwalia, I.J. (1991), Productivity and Growth in Indian Manufacturing, Oxford University Press, New Delhi.

Anant, T.C.A., Gangopadhyay, S. and Goswami, O. (1993), 'Industrial Sickness in India: haracteristics, Determinants and History, 1970-1990', mimeo: Indian Statistical Institute, New Delhi.

Ashenfelter, O. and Smith, R.S. (1974), 'Compliance with the Minimum Wage Law', Journal of Political Economy, vol. 87.

Basu, K. (1993), Lectures in Industrial Organization Theory, Blackwell: Oxford, U.K. and Cambridge, U.S.A.

Basu, K. (1997), 'Some Institutional and Legal Prerequisites of Economic Reform in India', in H.E. Bakker and N.G. Schulte Nordholt (eds.), Corruption and Legitimacy, SISWO Publications, Amsterdam.

Basu, K. (2004), 'Indian Economic Reforms: Up to 1991 and Since', in K. Basu (ed.), India's Emerging Economy: Performance and Prospects in the 1990s and Beyond, MIT Press, Cambridge, MA.

Basu, K., Fields, G. and Debgupta, S. (2001), `Alternative Labor Retrenchment Laws and their Effects on Wage and Employment', mimeo: Cornell University.

Basu, K., Genicot, G. and Stiglitz, J. (2003), `Minimum Wage Laws and Unemployment Benefets When Labor Supply is a Household Decision' in K. Basu, P.B. Nayak and R. Ray (eds.) Markets and Governments, Oxford University Press, New Delhi.

Besley, T. and Burgess, R. (2003), 'Can Labor Regulation Hinder Economic Performance? Evidence from India’, BREAD Working Paper No. 44.

Card, D. (1992), `Do Minimum Wages Reduce Employment? A Case of California, 1987-89', Industrial and Labor Relations Review, vol. 46.

Card, D. and Krueger, A.B. (1994), `Minimum Wages and Employment: A Case Study of the Fast-Foot Industry in New Jersey and Pennsylvania', American Economic Review, vol. 84.

Datta Chaudhuri, M. (1990), `Market Failure and Government Failure', Journal of Economic Perspectives, vol. 4.

Datta Chaudhuri, M. (1994), `Labor Markets as Social Institutions in India', CDE Working Paper No. 16, Delhi School of Economics. 
Dixit, A. and Stern, N. (1982), 'Oligopoly and Welfare: A Unified Presentation with Applications to Trade and Development', European Economic Review, vol. 19.

Drazen, A. (1986), `Optimal Minimum Wage Legislation', Economic Journal, vol. 96.

Edgren, G. (1989), 'Structural Adjustment, the Enterprise and the Workers' in G. Edgren (ed.), Restructuring Employment and Industrial Relations, I.L.O., Geneva.

Ehrenberg, R. (1994), Labor Markets and Integrating National Economies, Brookings Institution, Washington, D.C.

Encaoua, D. and Jacquemin, A. (1980), `Degree of Monopoly, Indices of Concentration and Threat of Entry', International Economic Review, vol. 21.

Fallon, P.R. and Lucas, R.E.B. (1993), 'Job Security Regulations and the Dynamic Demand for Industrial Labor in India and Zimbabwe', Journal of Development Economics, vol. 40.

Ghose, A.K. (1994), 'Employment in Organized Manufacturing in India', Indian Journal of Labor Economics, vol. 37.

Kannan, K.P. (1994), 'Levelling Up or Levelling Down? Labor Institutions and Economic Development in India', Economic and Political Weekly, 23 July.

Layard, R., Nickell, S. and Jackman, R. (1994), The Unemployment Crisis , Oxford University Press.

Lucas, R.E.B. (1988), 'India's Industrial Policy', in R.E.B. Lucas and G.F. Papanek (eds), The Indian Economy: Recent Developments and Future Prospects, Oxford University Press.

Mathur, A. (1991), Industrial Restructuring and Union Power: Micro-economic Dimensions of Economic Restructuring and Industrial Relations in India, I.L.O., Geneva.

Nagaraj, R. (1993), 'Employment and Wages in Manufacturing Industries in India', Discussion Paper 98, Indira Gandhi Institute of Development Research, Bombay.

Nichol, A.J. (1930), Partial Monopoly and Price Leadership, Press of Smith-Edwards Co., Philadelphia.

Papola, T.S. (1989), `Restructuring in Indian Industry: Implications for Employment and Industrial Relations' in G. Edgren (ed.), Restructuring Employment and Industrial Relations, I.L.O., Geneva. 
Papola, T.S. (1994), 'Structural Adjustment, Labor Market Flexibility and Employment', Indian Journal of Labor Economics, vol. 37.

Rama, M. (2000), `Downsizing in the Presence of Monopoly Rights: The Road to Riches', mimeo: Development Research Group, World Bank.

Ramaswamy, E.A. (1984), Power and Justice, Oxford Universitiy Press.

Ranis, G. (1994), `Labor Markets, Human Capital and Development Performance in East Asia', mimeo, Yale University.

Singh, J. (2000), Some Aspects of Industrial and Labor Markets in India: Perspectives from Law and Economics, Ph.D. Dissertation, Delhi School of Economics, Delhi University.

Shapiro, C. and Stiglitz, J.E. (1984), `Equilibrium Unemployment as a Worker Discipline Device', American Economic Review, vol. 74.

Stigler, G. (1950), `Monopoly and Oligopoly by Merger', American Economic Review, vol. 23.

Thorbecke, E. (2003), 'Poverty Analysis and Measurement within a General Equilibrium Framework', in C.M. Edmonds (ed.), Reducing Poverty in Asia, Edward Elgar, Cheltenham, U.K.

Thorbecke, E. (2003a), 'Conceptual and Measurement Issues in Poverty Analysis', mimeo: Cornell University. 


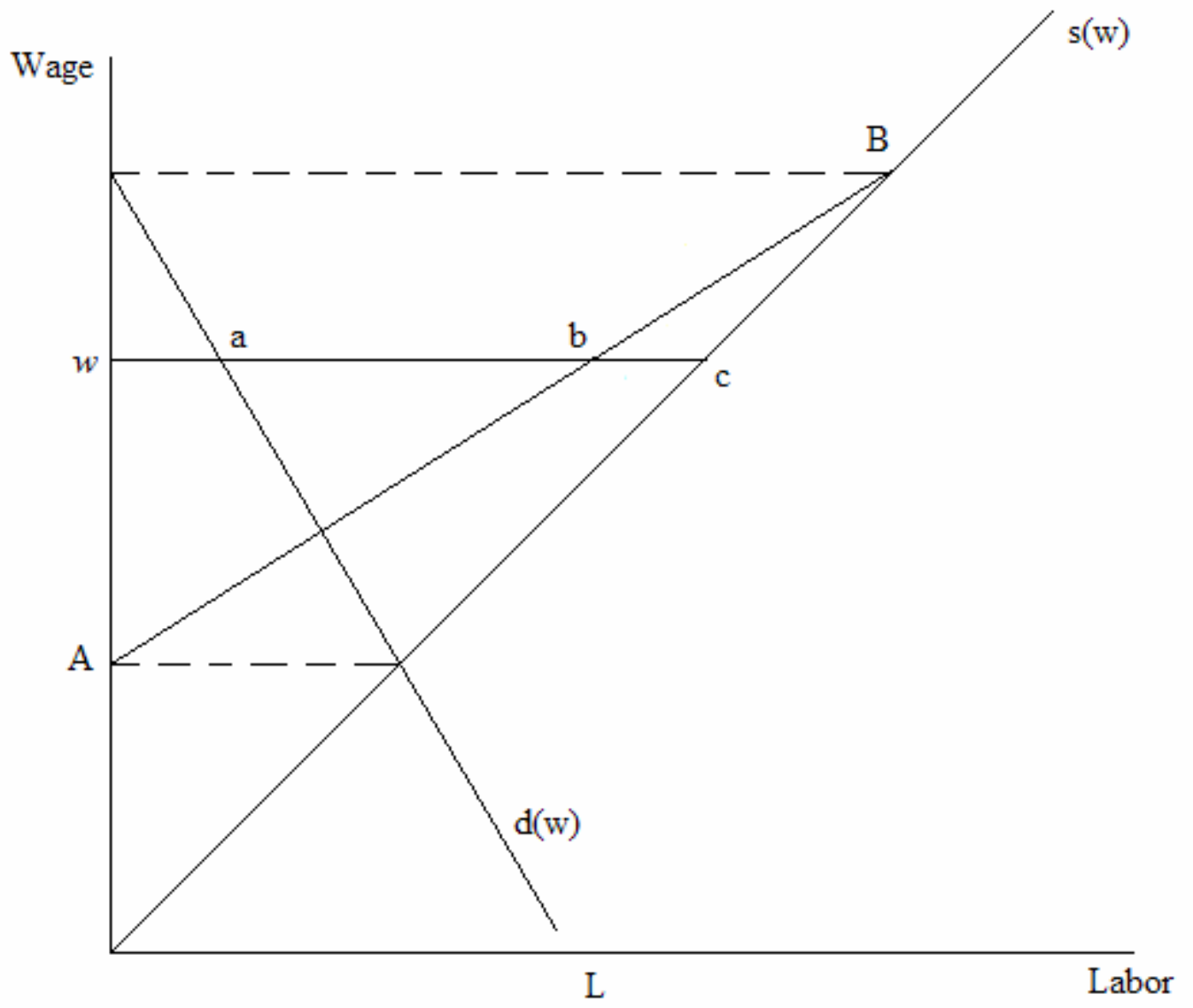

Figure 1 


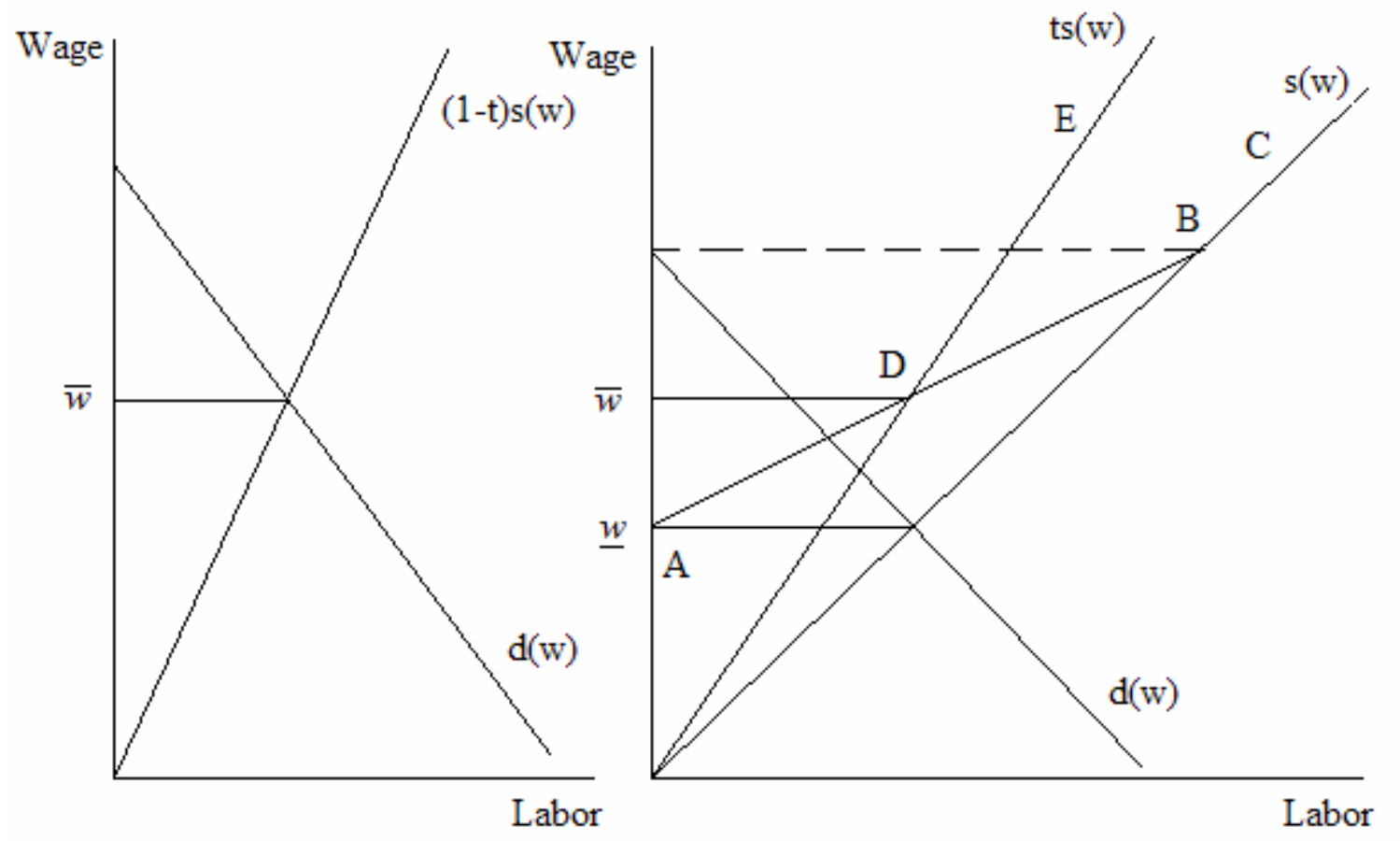

Figure 2 


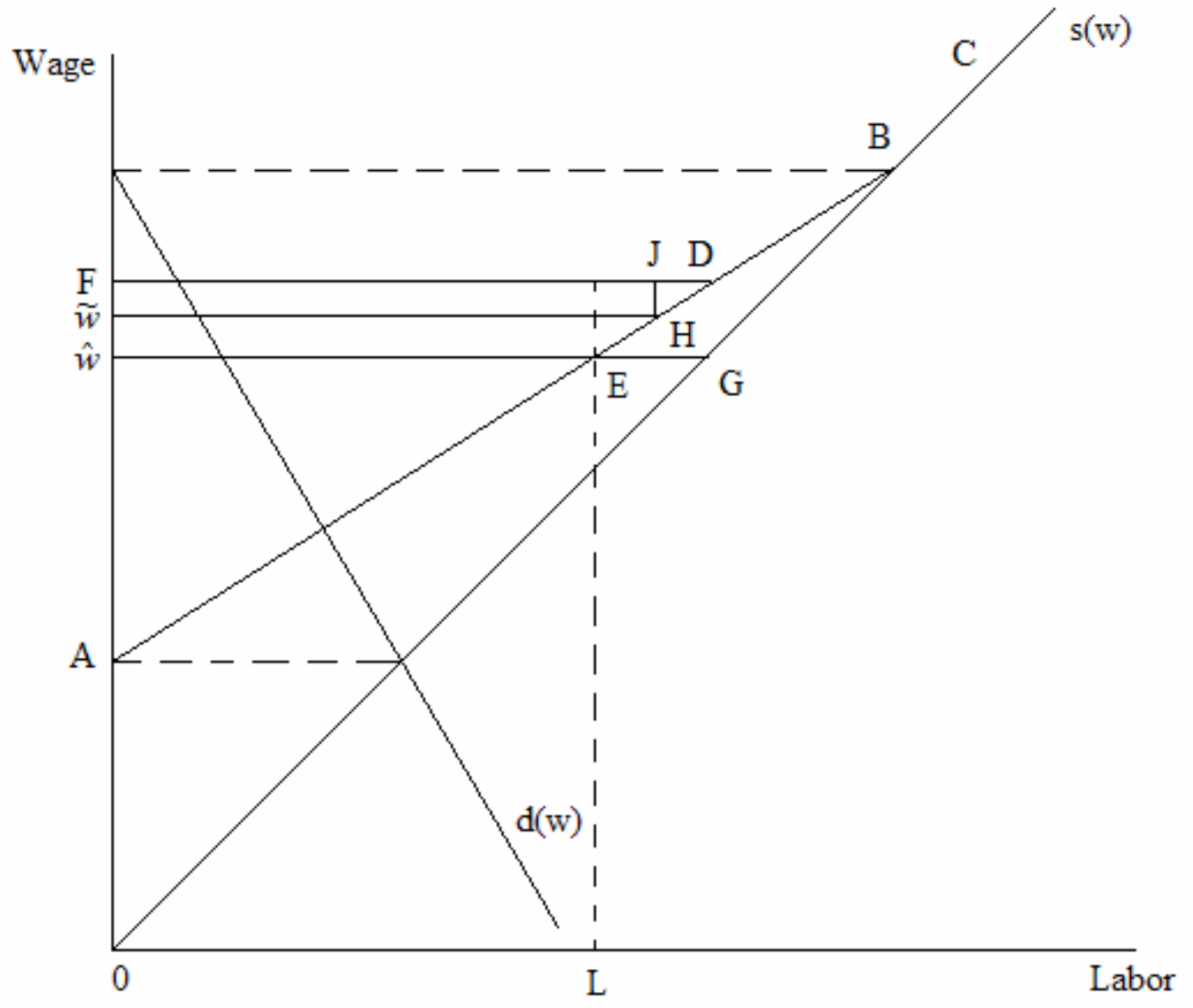

Figure 3 